\title{
Implications of Financial Repression on Economic Growth: Evidence from Nigeria
}

\author{
Francis Agboola Oluleye \\ Department of Economics and Development Studies Federal University Otuoke Bayelsa state
}

\begin{abstract}
This study set out to examine the effects of financial repression on economic growth using Nigeria's data and adapted form of McKinnon (1973) and Shaw (1973) models. McKinnon (1973) and Shaw (1973) found that financial repression retards economic growth. Our study found that they were right, that interest rate regulation and control negatively affect investment as low interest rate will discourage savings thereby depriving investment the needed funded and hence retard economic growth. Therefore, to make funds available for investment and enhance economic growth, monetary authorities will have to ease financial repression by raising or/and liberalizing interest rate.
\end{abstract}

(Keywords: Financial repression, interest rate, monetary authorities, economic growth)

JEL: E22; E41;E43; E5

\section{Introduction}

Interest rates are the rental payments for the use of credit by borrowers and return for parting with liquidity by lenders. The primary role of interest rates is to help in the mobilization of financial resources and to ensure the efficient utilization of such resources in the promotion of economic growth and development, (CBN, 1997). Interest rates affect both the level of consumption and the level and pattern of investments; they are crucial in financial intermediation, which involves the transfer of funds from surplus units in an economy to deficits units.

The classicals, Keynes and Keynesians and monetarists all showed that interest rate is a significant factor influencing the level of investment in an economy. According to the classicals, the surplus units of the economy decide whether to save or not taking into consideration the interest rate such that the higher the interest rate, the more willing they are to save a higher portion of their income and vice-versa. As noted by Gbosi (2005), in the view of the classical economists, the supply of capital is the same thing as savings. On the other hand, the deficit units (investors) decide whether to borrow for investments or not with reference to the market interest rate such that at lower interest rate, they plan increased levels of investments and vice-versa. Keynes (1936) concurred with the classicals that interest rate is a determinant of level investment, although he argued that expectation is another very important factor influencing level of investment which the classicals never considered or were silent about. Keynes, thus, noted that there is a very low level of interest rate at which people prefer to hold their money balances in form of cash (liquid). This, he called, 'liquidity preference' situation. The implication of this Keynes' discovery/contribution is that even though the investors are happy and more willing to increase their investments at low levels of interest rate, the funds for the investments may not available because at those low levels of interest rate, people might refuse to save but rather prefer to hold their money in form of cash. As a result of this constraint on investment due to low interest rate, which makes funds unavailable for investment, economic growth is retarded.

In a deregulated economy or free-market economy, it is not likely that interest rate would be so low as to be caught up in the 'liquidity preference trap' because of the activities of financial intermediaries. Such low levels of interest rate are usually experienced when the monetary authorities deliberately 'pegged' the rate at those low levels with the objective of boosting investments in the economy since investment is negatively related to interest rate. But because, at very low interest rate, the suppliers of funds prefer to hold cash rather than make it available for investment, it is said that finance is 'repressed'. Financial repression has implications on the growth of an economy.

R. McKinnon and E. Shaw built a model in 1973 to analyze the effect of financial repression on economic growth. They found that real rate of interest exerted a positive and significant effect on domestic saving and economic growth. They therefore recommended that financial conditions should be improved by ending financial repression.

Prior to 1986, interest rate was rigidly regulated in Nigeria. As part of the strategies of implementing the thrusts of Structural Adjustment programmed (SAP) in Nigeria, interest rate was deregulated in 1986 together with other economic variables. Even though deregulation is still the principle driving the Nigerian economy, interest rate is now being singly regulated. Deposit interest rate is being regulated in most underdeveloped countries with the aim of encouraging investments. Nigeria currently pegs deposit interest rate 
at between 3-5 percent in order to bring down lending rate and consequently the cost of funds and thus encourage investments. The fear is that this low level of deposit interest rate may discourage savings thereby lending credence to the liquidity preference hypothesis resulting in financial repression in Nigeria, which will adversely affect investment and hence economic growth.

Hence, this paper set out to examine the implications of low levels of interest rate on economic growth using McKinnon and Shaw model and Nigerian data.

In order to achieve the above objective, the paper is structured into five sections. Section 2 - theoretical framework - immediately follows the introduction. The materials and methods used in the study are contained in section 3 while section 4 contains the presentation and interpretation of estimated results and discusses the findings. Section 5 concludes the work and makes recommendations based on the findings and conclusion of the work.

\section{Theoretical framework}

The framework for this study is the model developed by R. McKinnon and E. Shaw. In 1973, R. McKinnon and E. Shaw tried to show that financial repression, as a result of very low interest rate, would hamper investment growth, which would consequently affect the rate of economic growth.

According to Ghatak (1980), the basic features of the McKinnon and Shaw model can be illustrated with the help of figure below:

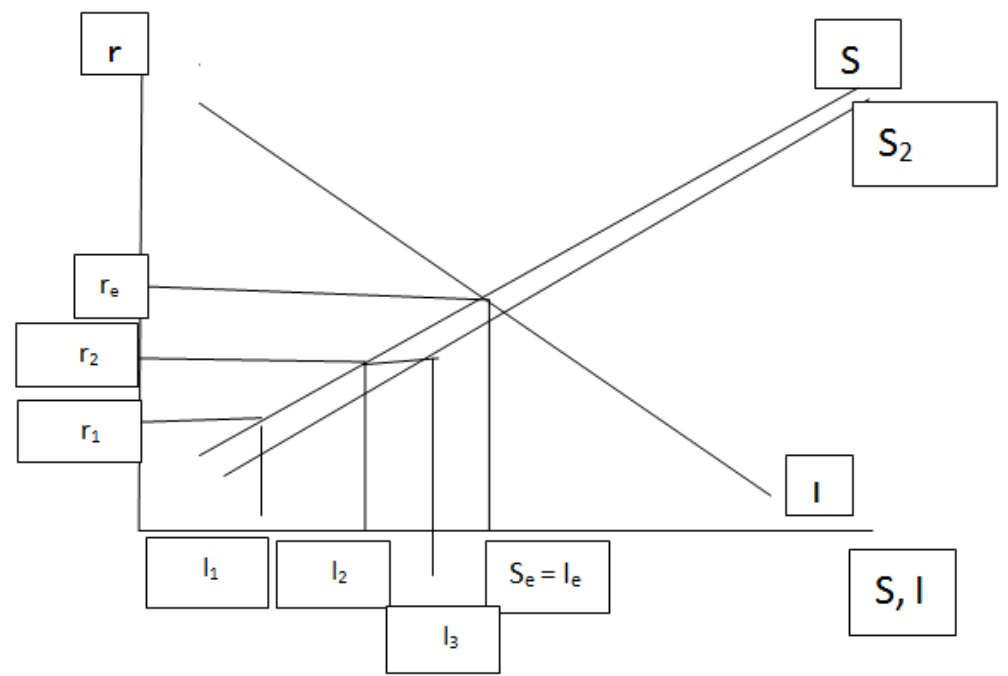

Let, $\mathrm{r}$, the real interest rate, be measured on the vertical axis and, savings, $\mathrm{S}$ and investment, I, be measured on the horizontal axis. Let savings be a positive function of real interest rate, and investment, a negative function of real interest rate. In a free market without any financial constraint, $r_{e}$ will be equilibrium real interest rate where $\mathrm{Se}=\mathrm{I}$. But because of a financial constraint or repression, the institutional interest rate given by $r_{1}$ is less than the free market equilibrium real rate $r_{e}$. The amount of actual investment is constrained to $I_{1}$ because of the limited saving that is available at $r_{1}$. This lends credence to the assertion of Keynes (1936) that, at a very low level of interest rate, people would prefer to hold their money balances in form of cash and thereby not making them available for investment.

If the monetary authorities decide to ease the financial repression and raise the real rate from $r_{1}$ to $r_{2}$, both savings and investment will rise. The low yielding investment activities will be eliminated and the overall efficiency of investment will increase. This will lead to a rise in income and saving and hence the saving curve will shift to the right to $S_{2}$. Hence, actual investment will rise to $I_{3}$. According to them, if the monetary authorities are bold enough to abolish financial repression altogether and decide to dispense with the ceiling on the interest rate, then the level of actual saving and investment will rise further leading to a further expansion of income.

Ghatak (1980), thus, observed that the model implies that an increase in the real rate of interest will induce the savers in the LDCs to save more, which will enable more investment to take place. This will raise the rate of growth of the economy. To this end, Shaw (1973) contended that saving, investment and financial intermediation would be sub-optimal when the real rate of interest is arbitrarily fixed at a point, which is much lower than its equilibrium level. Financial intermediaries are therefore commended by Ghatak (1980) for rendering a valuable service in raising the real rate of return to savers and in lowering the real costs to investors by providing liquidity and information. They also reduce the risks by diversifying the asset structures. 
The McKinnon (1973)'s model rests on the basic assumption that the higher the real interest rate, the greater will be the accumulation of money balances and the larger will be inducement to invest. Hence, McKinnon (1973) put forward a hypothesis related to the basic complementarity between money and physical capital contrast to the traditional theory where a substitution relationship is assumed. This complementarity is given in the following demand -for- money function.

$(\mathrm{M} / \mathrm{p}) \mathrm{d}=\mathrm{f}\left(\mathrm{I} / \mathrm{Y}, \mathrm{Y} / \mathrm{p}, \mathrm{d}-\mathrm{p}^{*}\right)$

where; $(\mathrm{M} / \mathrm{p}) \mathrm{d}=$ the real money demand

$\mathrm{I} / \mathrm{Y}=$ the ratio of investment to output

$\mathrm{Y} / \mathrm{p}=$ the real output

$\mathrm{d}-\mathrm{p}^{*}=$ real interest rate on deposits

$\mathrm{He}$ argues that conditions that make $\mathrm{M} / \mathrm{P}$ attractive to hold enhance rather inhibit private incentives to accumulate physical capital. In turn, large real money holdings are normally the result of the monetary system maintaining a high and stable real return to the holders of money. This complementarity hypothesis leads to policy conclusions about inflationary finance and deposit rates of interest for accelerating development.

McKinnoh's complementarily hypothesis could also be stated as follows

$\mathrm{I} / \mathrm{Y}=\mathrm{f}\left(\mathrm{r}, \mathrm{d}-\mathrm{p}^{*}\right)$

where $r=$ average rate of return on physical capital.

To show the complementarity, we have

$\mathrm{d}(\mathrm{M} \backslash \mathrm{p}) / \mathrm{d}(\mathrm{I} / \mathrm{Y})>\mathrm{o} \quad$ and $\quad \mathrm{d}(\mathrm{I} \backslash \mathrm{Y}) / \mathrm{d}(\mathrm{d}-\mathrm{p} *)>\mathrm{o}$

If domestic saving is equal to investment, then McKinnoh's model can be restated as:

$\mathrm{M} / \mathrm{p}) \mathrm{d}=\mathrm{f}\left(\mathrm{S} / \mathrm{Y}, \mathrm{Y} / \mathrm{p}, \mathrm{d}-\mathrm{p}^{*}\right)$

Shaw (1973) pointed out that the removal of financial repression via an increase in the real interest rate would provide greater incentives to save and invest and lead to a more efficient allocation of resources. Thus, the demand for money function in Shaw's analysis, as shown below, is similar to that of McKinnon's.

$(\mathrm{M} / \mathrm{P}) \mathrm{d}=\mathrm{f}\left(\mathrm{Y} / \mathrm{p}, \mathrm{c}, \mathrm{d}-\mathrm{p}^{*}\right)$

where $\mathrm{c}=$ the opportunity cost of money holding

In practice, the difference between real yield on government bonds (b) and (p)*, b-p*, is used as an estimate of c, (Ghatak, 1980). It should, however, be noted that Shaw did not assume any complementarity between money and physical capital since investors do not simply depend upon own - finance.

The Models Formulation

\section{Methods and Materials}

This study adapts the McKinnon and Shaw (1973)'s model in consonance with the objective of the study. From the works of McKinnon (1973) and Shaw (1973), money demand function can be stated as

$\mathrm{Md}=\mathrm{f}(\mathrm{I} / \mathrm{Y}, \gamma, \mathrm{i}, \mathrm{Md}-1)$

where $\mathrm{Md}=\mathrm{M} / \mathrm{p}=$ the real money stock

$\mathrm{I} / \mathrm{Y}=$ the ratio of investment to output

$\gamma=$ real output

$\mathrm{i}=$ real deposit rate of interest

$\mathrm{Md}^{*}-1$ = lagged value of real money demand

And investment function, which is the McKinnon's complementarity's hypothesis, can be stated as:

$\mathrm{I} / \mathrm{Y}=\mathrm{f}(\mathrm{r}, \mathrm{i})$

where $r=$ average rate of return in physical capital

Therefore, our model can be stated as:

$\mathrm{Md}=\mathrm{f}(\mathrm{I} / \mathrm{Y}, \gamma, \mathrm{i}, \mathrm{Md}-1)$.

$\mathrm{I} / \mathrm{Y}=\mathrm{f}(\mathrm{r}, \mathrm{i})$

Note: $\mathrm{r}$ will be measured by real yield on government bonds (using treasury bill rate)

Such that; $\mathrm{dMd} / \mathrm{d} 1 / \mathrm{Y}>0 ; \mathrm{dMd} / \mathrm{d} \gamma>0 ; \mathrm{dMd} / \mathrm{di}<0 ; \mathrm{dMd} / \mathrm{Md}-1</>0$

$$
\mathrm{dI} / \mathrm{Y} / \mathrm{dr}<0 ; \quad \mathrm{dI} / \mathrm{Y} / \mathrm{di}>0
$$

The above model indicates that a simultaneous relation exists among the variables - while I/Y is a determinant of $\mathrm{Md}, \mathrm{I} / \mathrm{Y}$ is also being determined in the model. Hence, there is need to identify the model.

\section{Model Identification}

The identification of a model is important to determine whether the statistical estimates of the equation in the model are unique or not. Statistic form of an equation will be unique if the equation is identified. A system is identified if its equations are identified.

There are two conditions for identification: order condition and rank condition. The order condition is given as $(\mathrm{K}-\mathrm{M}) \geq(\mathrm{G}-1)$

Where $\quad \mathrm{K}-\mathrm{M}=$ number of excluded variables 
$\mathrm{G}-1=$ total number of equations -1

$\mathrm{K}=$ number of total variables in the model

$\mathrm{M}=$ number of variables included in a particular equation.

$\mathrm{G}=$ total number of equations

For our model:

$$
\begin{aligned}
& K=7 \\
& G=2 \\
& (K-M) \geq(G-1)
\end{aligned}
$$

For equation 1 :

$7-5 \geq 2-1$

$2>1$ over - identified

For equation 2:

$$
7-3 \geq 2-1
$$

$4>1 \quad$ over - identified

Order condition indicates that the model is over - identified.

The rank condition states that "in a system of $\mathrm{G}$ equations any particular equation is identified if and only it is possible to construct at least one non-zero determinant of order $(G-1)$ from the coefficients of the variables excluded from that particular equation but contained in the other equations of the model.

From the model:

Variables

\begin{tabular}{|l|l|l|l|l|l|l|}
\hline & Md & I/Y & $\gamma$ & i & Mt - 1 & r \\
\hline Equation 1 & -1 & 1 & 1 & 1 & 1 & 0 \\
\hline Equation 2 & 0 & -1 & 0 & 1 & 0 & 1 \\
\hline
\end{tabular}

For equation 1:

Determinant of order $\mathrm{G}-1=-1,1$, or 0

The rank condition is also met is met for equation 1

For equation 2:

Determinant of order $\mathrm{G}-1=1$ or 0

The rank condition is met for equation is met for equation 2

Therefore, the model is over identified.

\section{Method of Estimation}

Since our model is a model of simultaneous relation and it is over - identified, the Two Stages Least Squares method (2SLS) of repression analysis is more suitable for the estimation of the parameters of the model. As koutsoyannis (1977) noted, it is good in the estimation of over-identified model.

\section{Model Evaluation}

The evaluation of the model will be done in the light of the following:

$>$ Apriori expectations regarding the signs of the parametric variables

$>$ Test of significance of parameter estimates (t-statistics) at $5 \%$ level

$>$ Goodness of Fit test $\left(\mathrm{R}^{2}\right)$

$>$ Adequacy of regression equation (F-test)

$>$ Test of autocorrelation (Durbin-Watson test)

\section{Type and Sources of data}

Time series data were collected for the period 1980 - 2014 denoting a period of 35 years. The sources of the data are Central Bank of Nigeria Statistical Bulletin (various volumes), International Financial Statistics, Central Bank of Nigeria Economic and Financial Review (Various volumes), Central Bank of Nigeria Annual Reports and Statements of Accounts (Various issues) and National Bureau of Statistics Annual Abstract of Statistics, 2009.

\section{Presentation and Interpretation of Estimated Results}

Although the nominal deposit interest rates in Nigeria remained positive over the period used for this study, the real interest rates were negative for some of the years. This implies that the diminution in the value of money was more than the addition to it by interest rate. 
Using the two-stage least squares estimator, the following results were obtained:

$$
\begin{gathered}
\mathrm{Md}= \\
(0.75) \quad(1.75) \quad(1.53) \quad(10.51) \quad(1.54)
\end{gathered}
$$

$$
\begin{array}{lll}
\mathrm{R}^{2}=0.92 & \mathrm{~F}=80.3 \quad \text { D. } \mathrm{W}=2.01
\end{array}
$$

$\mathrm{I} / \mathrm{Y}=0.83-0.195 \mathrm{r}^{*}+0.186 \mathrm{i}^{*}$

(1.32) (2.40) (1.86)

$\mathrm{R}^{2}=0.94 \quad \mathrm{~F}=85.3 \quad$ D. $\mathrm{W}=1.99$

(Note $*$ indicates natural logarithms)

The obtained results are quite good. In equation 1, the explanatory variables are able to explain 92 percent variations in the dependent variable. At 5 percent level, the F-value is highly significant and the tstatistics indicate that all the explanatory variables except lagged value of real money demand are statistically significant. All the variables also met the expected signs. In equation 2, all the variables met the expected signs. The explanatory variables explained 94 percent of the changes in the dependent variable. At 5 percent, only real deposit interest rate is significant. The F-statistic indicates that the model is adequate. In the two equations, the D.W statistic indicates absence of serial correlation. In any case, two-stage least squares has the ability to correct for serial correlation. It should be noted that since the variables are in logarithms, the coefficients represent elasticities which measure the direct effect of the explanatory variables on the dependent variables.

\section{Steady-State or Long-Run Coefficients}

As a further analysis of the regression results, we examined the steady-state or long run coefficients of equation 1. To do this, we set $\mathrm{Md}=\mathrm{Md}-1$. This gives:

$$
\mathrm{Md}^{*}=0.065+0.3 \mathrm{I} / \mathrm{Y}^{*}+0.067 \gamma^{*}-0.168 \mathrm{i}^{*}
$$

The above analyses show that ratio of investment to output, real output and real deposit rate of interest have greater impact on real money demand in the short run than in the long run as judged by their elasticities. In other words, money demand is more elastic in the long-run than in the short run with respect to the explanatory variables. For instance, while a 3 percent change in the ratio of investment to output will cause 1 percent change in the demand for money in the long run, only 2.4 percent change in the ratio of investment to output will cause a 1 percent change in money demand in the short run.

For equation 2, the model did not differentiate between short run and long run as the lagged value of the dependent variable was not included.

\section{Discussion of Findings}

Since deposit interest rate is negatively and significantly related to money demand in both the short run and long run, it implies that the higher the interest rate, the more willing people are to save their money rather than hold it. These savings will make more funds available for investment. In the same vein, lower interest rate will induce people to hold their money in cash rather than save it which will deprive investment the needed fund.

Also equation 2 reveals that there is a positive and significant relationship between ratio of investment to output and interest rate, implying that as interest rate increases, investment also increases as a result of the availability of more funds for investment. Repressing finance, therefore, through interest rate control, will have negative effect on economic growth. These findings are in consonance with the findings of Vogel and Buser (1976).

\section{Conclusion}

Interest rate regulation is one monetary policy usually favoured in many economies, particularly LDCs. The belief is that if interest rate is not regulated, cost of borrowing would be beyond the reach of potential investors. The policy of regulating interest rate will also, no doubt, affect the willingness of savers to save. Mckinnon (1973) and Shaw (1973) showed that when finance is repressed through interest rate regulation by pegging it at a level far below the equilibrium, it will negatively affect the availability of funds for investment.

Our study, using Nigeria's data, shows that Mckinnon (1973) and Shaw (1973) were right. We found that there is negative and significant relationship between money demand and interest rate and positive and significant relationship between ratio of investment to output and interest rate. To this end, it is recommended that the monetary authorities should ease the financial repression and raise deposit interest rate or liberalize interest rate. 


\section{References}

[1]. Gbosi, A.N. (2005). Money, Monetary Policy and the Economy, Uyo: Abigab Associayes

[2]. Ghatak, S. (1995). Monetary Economics in Developing Countries, $2^{\text {nd }}$ ed, New York: St. Martins Press

[3]. Keynes, J.M. (1936). The General Theory of Employment, Interest and Money, London: Macmillian Press Ltd

[4]. Koutsoyannis, A. (1977). Theory of Econometrics, Basingstoke: Macmillian Press Ltd

[5]. Mckinnon, R. (1973). Money and Capital in Economic Development, Brookings Institute, Washington

[6]. Shaw, E. (1973). Financial Deepening in Economic Development, Oxford: Oxford University Press

[7]. Vogel, R. and Buser, S. (1976). Inflation, Financial Repression and Capital Formation in Latin America, In R. Mckinnon (ed), Money and Finance in Economic Growth and Development, Dekker, New York 